\title{
Editorial - Volume 2
}

\section{New routes in the study of Aviation and Aeronautical English}

This text is the Editorial for the second volume of the The Especialist Aviation English special edition. For a contextualization of $\mathrm{ICAO}^{1}$ Language Proficiency Requirements and for the conceptualization and theoretical background of Aviation and Aeronautical English, please consult the Editorial - Volume 1. There you will also find information about how this special edition was conceived and a list of other compilations related to Aviation English. The second volume presents the following papers:

Starting with Aeronautical Meteorology, Rafaela Rigaud Peixoto and Janine Pimentel focus on the Meteorology Terminology used by Brazilian experts and discusses whether Aeronautical Meteorology is a hybrid field. Based on the theory of lexical semantics for terminology, the syntactic and semantic properties of a small set of Portuguese terms were analyzed in two separate textual corpora, representative of Aviation language and Aeronautical language. Quantification and comparison of the results obtained suggest that the behavior of the terms in the two corpora share a fair amount of similarities.

In this volume, two papers tackle language descriptors that are assessed on the ICAO Rating Scale. The paper by Angela Carolina Moraes Garcia and Janna Fox investigates the nature of the listening tasks performed by pilots during radiotelephony communications in order to inform the development of the listening test construct and the test specifications. Through an explanatory sequential mixed-methods study, quantitative and qualitative data were analyzed, and findings were merged. Carlos Alberto Babboni and Karin Quast point out international air incidents and accidents in which pronunciation was one of the contributing factors, and then, based on the Lingua Franca Core, discuss the causes of some Brazilian speakers pronunciation difficulties, aiming to increase teachers' and students' awareness and to contribute to pronunciation teaching in the field of aeronautical

\footnotetext{
${ }^{1}$ International Civil Aviation Organization.
} 
English,while problematizing the non-critical use of textbooks by teachers and the inadequate training in English Language Phonology.

Moonyoung Park and Sarah Huffman's paper reports on the creation of an aeronautical English training unit based on the ADDIE (analysis, design, development, implementation, and evaluation) model of instructional design developed to assist Korean Army enlisted soldiers and noncommissioned officers who are serving as air traffic controllers in the improvement of integral ATC English skills. Results of the evaluation demonstrate the potential for application of the ADDIE model of instructional design for future ESP instructional units.

Still on the topic of initial training, two papers deal with pilots training. Marcus Bieswanger, Malila Prado and Jennifer Roberts, each in a different part of the world, revisit ongoing research on needs assessment of the language employed in ab initio pilot training, particularly the training held in English speaking countries. The objective is complementing the needs assessment of the already existing language courses prior to flight training with ongoing research about English as a Lingua Franca (ELF). It is worth mentioning that, in many countries, airline companies recruit candidates for pilot jobs and send them abroad so that these candidates can receive flight training alongside language training, in the assumption that pilots will be better prepared if they are immersed in the English language culture. In the following paper, Jena Lynch and Adriana Porcelatto examine how these nonnative English-speaking students are selected to USA flight training organizations and offer an analysis of the only test suited for the purpose in the market nowadays. Results point out a need for a deeper understanding of the flight training domain through observation, collection and analysis of written and spoken texts that are typical of this context. The paper also highlights characteristics that a good test for selection purposes should contain.

The two other papers were based on aviation professionals' experience and opinions about aeronautical language. Beatriz Faria Aragão and Matilde Scaramucci present an analysis and a discussion, using a focus group methodology, of the language tasks listed in Appendix B of the Manual on the Implementation of Language Proficiency Requirements (Doc 9835, ICAO, 2010). Although those language tasks supposedly represent language used by ATCO, they were considered too vague to be used to develop teaching and assessment materials. Results show that the most frequent language tasks are related to traffic management, mostly covered by phraseology. On the other hand, language tasks involving explanation and clarifications, which are highly recurrent in radiotelephony communications, require the use of plain language. Their analysis also revealed that some language tasks might not be so complex in terms of language, but play an important role in safety. It is noteworthy that this paper presents the ICAO Rating Scale in the Appendix. 
To conclude, Gareth Williams and Lynn Clark present a survey that queried 555 pilots and ATCOs from all over the world about the nature and frequency of poor language proficiency they experience in international operations. The data shows evidence that there is a relatively frequent problem with language proficiency among pilots and ATCOs and that some regions of the world are experiencing it more acutely than others.

We would like to express our gratitute to all the authors for believing in this project. No one could predict the coronavirus pandemic, but it did not stop us. Thank you for persevering despite all difficulties.

We would like to thank the reviewers of this special edition, who shared their precious time and knowledge with us even in the middle of the pandemic. They are, in alphabetical order: Adilson Cleômenes Rocha, Ana Bocorny, Bento Dias da Silva, Cláudia Hilsdorf Rocha, Dilso Almeida, Gladys Quevedo-Camargo, Juliana de Castro, John Corbett, Maria del Pilar Troncoso Unwin, Maria José Finatto, Matilde Scaramucci, Miriam Retorta, Paula Tavares Pinto, Paula Ribeiro e Souza, Rosinda Guerra Ramos, Sandra Gattolin, Sandra Navarro-Fuchs, Silvia Damião, Simone Sarmento, Solange Aranha, Stella Tagnin and Thaïs Cristófaro Silva.

A special thanks to Rafaela Rigaud Peixoto, who translated all titles, abstracts and key-words from foreign authors' papers into Portuguese.

We must thank the Department of Airspace Control (DECEA) and the Airspace Control Institute (ICEA) for supporting our research group GEIA ${ }^{2}$. We invite our readers to visit the 7 th GEIA Seminar website https://geia.icea.gov.br/geia/viiseminariogeia/ to see the faces and hear the voices of the papers' authors. They all recorded videos introducing themselves and their research for the 2020 virtual edition of the GEIA Seminar.

Last but not least, we would like to thank Adolfo Tanzi Neto, Editor-in-Chief, for all his support and for embracing this project since its very beginning. We will be forever grateful to him, to The Especialist Editorial Board and to the Pontifical Catholic University (PUC-SP) for this opportunity of uniting the world under the shiny sky of Aviation English. Have a nice flight.

Patrícia TOSQUI-LUCKS (ICEA) ${ }^{3}$ Malila Carvalho de Almeida PRADO (FJUT) ${ }^{4}$

\footnotetext{
${ }^{2}$ Grupo de Estudos em Inglês Aeronáutico. In English: Aeronautical English Research Group. https://geia.icea.gov.br/geia/home.php

${ }^{3}$ Airspace Control Institute (ICEA), São José dos Campos, SP, Brazil. Aeronautical English Section, Teaching Department. ORCID: https://orcid.org/0000-0001-9104-2123; patricialucks@gmail.com

4 Fujian University of Technology, Fuzhou, Fujian, China. School of Humanities; ORCID: https://orcid.org/0000-00016281-6759; malilaprado@hotmail.com
} 


\section{References}

BORGES, A., 2016. Santos Dumont: the flying poet. V!RUS, [e-journal] 12. Available at: $<$ http://www.nomads.usp.br/virus/virus12/?sec=5>. Accessed: 11 Oct 2020.

ENRIGHT, A.; Borowska, A. (Eds.) 2016.Changing Perspectives on Aviation English Training, Studi Naukowe 29, University of Warsaw.

HANSEN-SCHIRRA, S.; K. MAKSYMSKI. 2013. Aviation Communication: Between theory and practice. Germershein, FTSK62, Peter Lang Edition. p. 33-42.

INTERNATIONAL CIVIL AVIATION ORGANIZATION/ICAO. 2010. Doc. 9835 AN/453: Manual on the implementation of ICAO language proficiency requirements. 2. ed. Montreal.

INTERNATIONAL CIVIL AVIATION ORGANIZATION/ICAO. 2004. Doc. 9835 AN/453: Manual on the implementation of ICAO language proficiency requirements. 1. ed. Montreal.

INTERNATIONAL CIVIL AVIATION ENGLISH ASSOCIATION Conference Proceedings. 2019.

Tokyo, Japan. Available at: $<$ https://commons.erau.edu/icaea-workshop/2019/proceedings/1/>.

Accessed: 11 Oct 2020.

INTERNATIONAL CIVIL AVIATION ENGLISH ASSOCIATION Conference Proceedings. 2018.

Daytona Beach, Florida, USA. Available at: $<$ https://commons.erau.edu/icaea-

workshop/2018/proceedings/>. Accessed: 11 Oct 2020.

INTERNATIONAL CIVIL AVIATION ENGLISH ASSOCIATION Conference Proceedings. 2017.

Dubrovnik, Croatia. Available at: $<$ https://commons.erau.edu/icaea-workshop/2017/monday/ $>$.

Accessed: 11 Oct 2020.

ROEVER, C. Editorial. In: READ, J; U. KNOCH. (Eds.) 2009. Australian Review of Applied Linguistics. 32.3: 20-1.

SCARAMUCCI, M.V.R.; P. TOSQUI-LUCKS; S.M. DAMIÃO (Eds.). 2018. Pesquisas sobre inglês aeronáutico no Brasil. Campinas: Pontes Editores.

TERENZI, D. (Ed). Revista CBTecLE no 1 - 2020 (Inglês na Aviação) v. 2, n. 1. Available at: < https://revista.cbtecle.com.br/index.php/CBTecLE/issue/view/v.2\%2Cn.1\%20\%282020\%29>.

Accessed: 11 Oct, 2020.

TOSQUI-LUCKS, P.; S.M DAMIÃO; M.V.R. SCARAMUCCI. 2018. Panorama das pesquisas sobre inglês aeronáutico no Brasil - Contribuições para a segurança de voo. Conexão SIPAER. Revista Científica de Segurança de Voo, 9.2: 50-64. 